\title{
送風防霜法に抢けるチャ樹冠面の風速と葉温上昇量との関倸
}

\author{
静岡県農林技術研究所茶業研究センター* \\ 中野敬之 之 $^{\dagger}$ \\ パナソニック環境エンジニアリング株式会社** \\ 関口幸彦・成田和隆
}

(平成26年 8 月 28 日受理)

\section{Relationship of Wind Speed and Canopy Leaf Temperature Rise for Air Stirring Frost Protection in Tea Field}

\author{
Takayuki Nakano $^{\dagger}$ \\ Shizuoka Prefectural Research Institute of Agriculture and Forestry, Tea Research Center \\ Yukihiko Sekiguchi \& Kazutaka Narita \\ Panasonic Environmental Systems \& Engineering Co., Ltd.
}

\begin{abstract}
Summary
Wind speed and leaf temperature under wind machine running were measured in frost nights. Hot-wire anemometers and thermometers were placed side by side on bush canopies in terms of distance $5.4 \mathrm{~m}, 10.8 \mathrm{~m}, 16.2$ $\mathrm{m}, 21.6 \mathrm{~m}, 27.0 \mathrm{~m}$ points ahead of the wind machine. Wind speed showed a maximum at $10.8 \mathrm{~m}$ point closest to the wind machine, but changed smaller as distance. Leaf temperature rise showed a maximum at $5.4 \mathrm{~m}-10.8 \mathrm{~m}$ points, but changed smaller as distance. Between 10.8 - $27.0 \mathrm{~m}$ points, leaf temperature rise seemed to increase as wind speed was large. Leaf temperature rise was greater amount despite wind speed is small at $5.4 \mathrm{~m}$ point. From these results, frost-protective effect of the air stirring method is dependent on the leaf temperature rise caused by the wind hits the tea bush canopy, but on another factor in the range close to the wind machine.
\end{abstract}

Key words : Air Stirring Method, Frost Protection, Leaf Temperature, Tea, Wind Speed.

キーワード : チャ, 防霜, 送風法, 葉温, 風速

\section{1 緒 言}

凍霜害は一番茶の安定生産を脅かす気象災害で, 中山
間部の茶産地を中心にこれまで多くの被害を及ぼしてき た ${ }^{1)}$ 。現在, 国内茶産地で最も普及されている対策は防 霜ファンによる送風法であるが，その起源は古く，1914 年にドイツのブドウ畑で試みられたのが最初と言われて

* 4 439-0002 静岡県菊川市倉沢1706-11

** T486-8524 愛知県春日井市鷹来町字上仲田3905-3

† Corresponding author : takayukil_nakano@pref.shizuoka.lg.jp 
いる ${ }^{2)}$ 。日本国内の茶園での最初の試みは, 1928年に奈 良県で煙霧を茶園上空に漂わせるために送風機が用いら れたが，効果範囲が狭かったとされている ${ }^{3)}$ 。1960年代 になると, 高橋ら ${ }^{4)}$ や木村ら ${ }^{5)}$ が地上 $1.5 \mathrm{~m}$ 程の高さか ら加熱した暖かい空気を送風する装置を試作・検討し, ある程度の温度上昇効果が認められた。しかし, エンジ ンを用いた大型の送風機が実用的でなかったからか，ほ とんど普及されなかった。このように, 約50年前まで茶 園で試みられた送風法は, 人工的に発生させた物質を茶 園に送り込むためのものであった。

ところが，1970年代前半に1,000W以下の電動小型送 風機が開発されると, 静岡県, 三重県, 埼玉県などを中 心として全国的に茶園への応用試験が展開され ${ }^{3,6)}$, ほ ほ同時に普及が始まった。この技術がそれまでと大きく 異なる点は, 単に送風機の小型化に成功したのみではな く, 送風機を地上 $5 \sim 6 \mathrm{~m}$ に設置し, 放射冷却で温度低 下した地表面に高所の暖かい空気を吹き下ろすことをね らいとしたことである。この機種に関する当時の試験成 績は多数あるが ${ }^{3)}$, 研究論文として残っている資料は非 常に少なく，此本らは地上 $6 \mathrm{~m}$ に設置した750〜 950Wの 3 機種について検討した結果, 樹冠面の葉温上昇と実際 の降霜に扮ける被害芽率の低下を認め, 防霜ファン 1 台 当たりの効果範囲を 250 〜 $300 \mathrm{~m}^{2}$ とした ${ }^{6)}$ 。

1979年に広域で大規模な凍霜害が発生した。当時にお ける静岡県の茶園面積22,000haに対して, 防霜ファンの 設置面積は僅か526haであったとされている7)。しかし， 被覆法に比べて効果が安定していたことから送風法の評 価は急激に高まって, 翌年以降は毎年数百haの規模で 設置が進み, 2011年現在での設置面積は9,170haに達し ている ${ }^{1)}$

このように，今では茶園での主要な防霜対策となって いる送風法であるが, 普及当初の1970年代以後の研究例 は少なく, 防霜の理論や技術は当時のままでほとんど変 わっていない。特に, 茶や農業気象関係の書籍では, 「高 所の暖かい空気と地表近くの泠たい空気を混合し，放射 冷却で冷えた作物体温を直接暖める」 ${ }^{8)}$ ，「暖かい空気 を下方に吹き降ろすことにより茶株面付近の気温を高め る」 ${ }^{9)}$, 「夜間にできる地表付近の逆転層を摚拌し, 茶 株周辺の気温を上昇させる」 ${ }^{10)}$,「ファンで耕地の空気 をかき混ぜてー上層の暖かい空気を下方に吹き付けて一 地面付近の気温を暖める」 ${ }^{11)}$ 等と解説されており, 総 じて「地表（地面, 茶株面, 接地) 付近の空気 (気温) を暖める」ことが防霜効果の原理との解釈が伝承されて いる。
ところで, 筆者らは, 熱映像温度計でファン稼働によ る茶園内の温度分布を観測したところ, 温度上昇部分は ファンの首振りに伴って左右に大きく動き, 風が直接当 たっている部分のみ温度が上昇している現象が認められ た ${ }^{12)}$ 。また, 地上 $3 \mathrm{~m}$ に設置したファンを下方へ 5 度傾 けて樹冠面上に風を流すようにすると温度上昇量は少な く，下方へ10度以上傾けて樹冠面に直接風が当たるよう にすると温度上昇が大きかった ${ }^{13,14)}$ 。これらの結果は, 送風法の防霜効果が植物体付近の空気を暖めることでは なく, 風が植物体に直接当たって暖めることを示唆して おり，従来からの解釈を再検討する必要がある。

そこで，筆者らは，茶園内に風速計と温度計を併せて 配置し, ファンの稼働によって変動する樹冠面での風速 と葉温上昇量との関係を調査して, 風が樹冠面に直接当 たって暖める効果について検討した。

\section{2 材料および方法}

試験は, 静岡県農林技術研究所茶業研究センター（静 岡県菊川市倉沢1706の11）のA 6 ほ場で実施した。供試 園は, 1984年 4 月に $180 \mathrm{~cm} \times 30 \mathrm{~cm}$ の単条植えで南北う

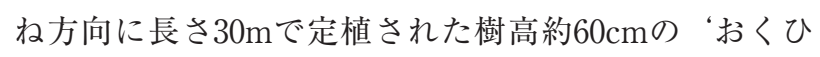
かり' 園で, 樹冠面の形状が曲率半径 $3000 \mathrm{~mm}$ の乗用 型摘採機で管理されている。防霜ファンは供試園の西端 に設置されている。

図 1 に示した実験機器の配置により，2005年 1 月18日 〜 4月26日の夜間（20：00～翌日 8：00）にタイマー制 御によって, 30分間隔で高位置（地上 $7 \mathrm{~m}$, 俯角 40 度） と低位置（地上 $3 \mathrm{~m}$, 俯角 20 度）のファン (パナソニ ック環境エンジニアリング株式会社製, 羽根径 : $90 \mathrm{~cm}$, 出力: $2.2 \mathrm{kw}$, 首振り角度: 120 度, 首振り速度: 0.55 回/分) を交互に15分ずつ稼働させ, 供試園の西端から東に向か って送風した。この設定では, 計算上, 地上 $7 \mathrm{~m}$ ファン からの送風はファンから $7.6 \mathrm{~m}$ 先, 地上 $3 \mathrm{~m}$ ファンは $6.6 \mathrm{~m}$ 先の方向に送風していることになる。

なお, タイマーはダイヤルによるアナログ形式なので, 実際に防霜ファンが稼働する時刻には数分間のずれが懸 念された。このため, 防霜ファンが実際に稼働している 時間帯は配電盤から後述するデータロガーに電圧信号を 出すよう配線を行った。

図1の(1)〜(5)に示したように, 防霜ファンから $5.4 \mathrm{~m}$ 間 隔で樹冠面の頂部に熱線風速計（日本カノマックス株式 会社製，型式0964-01）を設置し，その30cmほど横の葉 裏に熱電刘温度計（JIS type T, $\phi 0.3 ）$ をセロンテー 


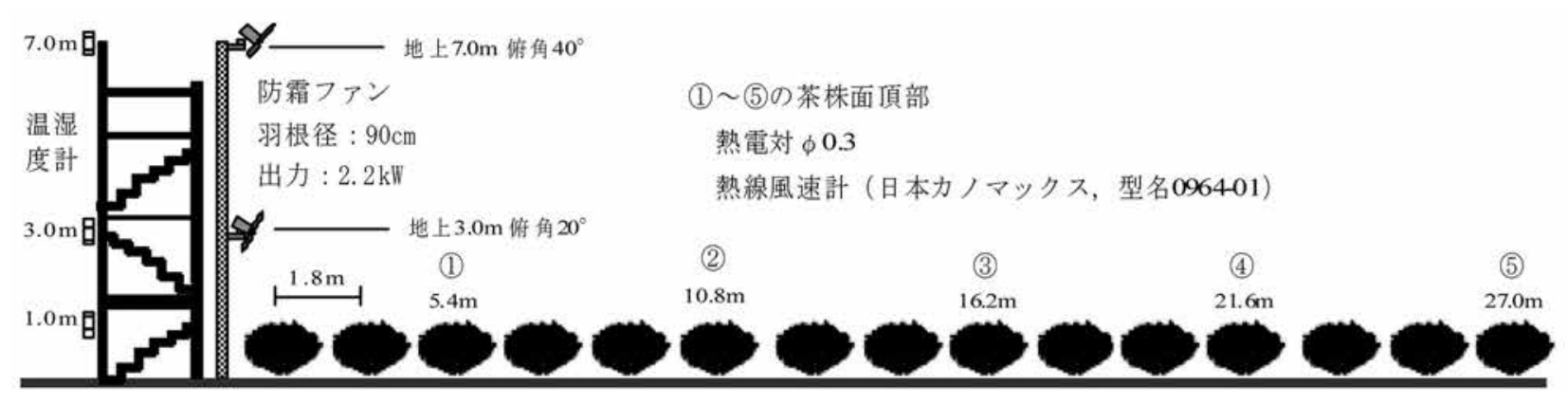

図 1 実験施設の概要と観測機器の配備

プで接着した。防霜ファンの西側にある櫓の地上 $1 \mathrm{~m}$, $3 \mathrm{~m}, 7 \mathrm{~m}$ の高さに自然通風シェルター（コナーシステ ム株式会社製, 型式KDC-A1-12) を被せた温湿度計 (ヴ アイサラ株式会社製，型式HMP45A）を設置した。ま た，(1)の位置に放射収支計（英弘精機株式会社製, 型式 $\mathrm{MF}-11$ ）を設置した。以上の観測データは全て 1 分間 隔で測定され，データロガー（アドバンテスト株式会社 製，R7326B）を介してノート型のパーソナルコンピュ ータに記録した。

\section{3 結 果}

試験を開始した2005年 1 月18日から 3 月18日の19： 00 翌 7 ：00における地上 $1 \mathrm{~m}, 3 \mathrm{~m}, 7 \mathrm{~m}$ の気温, 葉 温, 気温と葉温の格差, 風向風速および正味放射量の 平均值を表 1 に示した。高さ別の気温では, 地上 $7 \mathrm{~m}$ と $3 \mathrm{~m}$ の差はほとんどなく, 地上 $7 \mathrm{~m}$ は地上 $1 \mathrm{~m}$ より 0.1 $1.1^{\circ} \mathrm{C}$ 高かった。しかし, 葉温は気温よりも0.9〜6.1 ${ }^{\circ} \mathrm{C}$ 低 く, その差は正味放射量が低い時に大きくなる傾向であ った。

凍霜害が発生する実際の場面では，晴天で正味放射量 が低く風のない夜間, 放射冷却によって地表面の空気が 上空よりも低下する接地逆転層が発生する場合に生じる

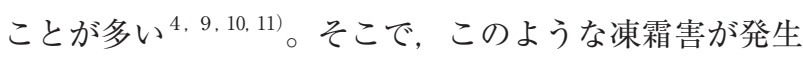
する条件に近い気象条件として, (1)地上 $1 \mathrm{~m}$ と $7 \mathrm{~m}$ の気 温較差が大きい, (2)気温が $0{ }^{\circ} \mathrm{C}$ 以上でも葉温が水点下を 記録している, (3)風速が $1.5 \mathrm{~m} /$ 秒以下の微風条件, (4)夜 間の正味放射量が- $0.090 \mathrm{~kW} / \mathrm{m}^{2}$ 以下となる期日を選び, データ解析の対象とした。

本研究におけるデータの解析方法と手順については, 具体例として2005年 1 月 21 日の観測データを使って説明 する。1月21日19：00から 1月22日8：00までにおける ファンからの距離 $5.4 \mathrm{~m}$ と $16.2 \mathrm{~m}$ 地点の葉温と風速を図 2
に示したが, ファンが稼働している時間帯は葉温と風速 が明らかに高まった。

次に, 図 2 中のaで示した 1 月 21 日 $21: 15 〜 22: 20$ に おける葉温と風速の推移を図 3 に示した。ファンの配電 盤から送られた電圧信号を確認してみると, この間で は地上 3 mファンは $21: 26 〜 21: 42$, 地上 $7 \mathrm{~m}$ ファンは 21：55～22：13に稼働しており，その間の葉温は高まり 風速が大きかった。ただ，図 3 を詳細に見ると，ファ ンが稼㗢してから葉温が十分に高まるまでに $2 \sim 3$ 分か かっていること, ファンが停止しても葉温が下がりきる まで，数分かかることが伺われた。したがって，ファン の稼働を開始した 6 分後から 10 分後までの葉温の平均值 （図 3 のd）と稼働直前 5 分間の葉温の平均值（図 3 の） との差を, ファン稼働による葉温上昇量 $\left({ }^{\circ} \mathrm{C}\right)$ とした。 一方, ファン稼働による樹冠面の風速については, 葉温 上昇量との関係を比較検討することから, 葉温上昇量を 算出した同じ時間帯（図 3 のd）での平均值を用いるこ とにした。

本研究では20：00から翌 $7: 30$ ま゙30分間隔で地上 $7 \mathrm{~m}$ ファンを 12 回, 地上 $3 \mathrm{~m}$ ファンを 11 回稼働させたが, 図 2 を詳細にみると, $19: 30$ 頃の実験開始直前の葉温は ファン稼働前後の葉温よりもかなり低く, その一方, 7 : 00以後の陽光が差し込む頃から葉温は上昇した。このた め, 気象条件が安定している21:30〜翌 6:30（図 2のb） において 2 機のファンが 9 回ずつ稼働した時間帯のデー タを集計することにした。

上記の方法で先に選定した調査日毎に集計し, 地上 $7 \mathrm{~m}$ と $3 \mathrm{~m}$ ファンを 9 回ずつ稼働させた時の樹冠面の風 速と葉温上昇量との関係について集計した。図 4 には, 代表例として，2005年 1 月21日，2月 3 日，2 月 5 日， 2 月 13 日， 2 月 20 日， 2 月 27 日， 3 月 1 日， 3 月 6 日， 3 月18日のデータを示した。なお, 眓 4 には, 最も相関 係数が高かった対数の近似曲線を書き加えた。 
表 1 試験期間における19：00〜翌07：00までの気温，風速，正味放射量の平均値と最低葉温

\begin{tabular}{|c|c|c|c|c|c|c|c|c|c|}
\hline 月日 & $\begin{array}{l}\text { 地上 } 7 \mathrm{~m} \\
\text { 気温 } \mathrm{a}\end{array}$ & $\begin{array}{l}\text { 地上 } 3 \text { m } \\
\text { 気温 }\end{array}$ & $\begin{array}{l}\text { 地上 } 1 \mathrm{~m} \\
\text { 気温. b }\end{array}$ & 葉温 c & $\begin{array}{c}\text { 温度格差 I } \\
\text { a-b }\end{array}$ & $\begin{array}{c}\text { 温度格差 II } \\
\text { (逆転度) } \\
\mathrm{a}-\mathrm{c}\end{array}$ & 風向 & 風速 & 正味放射量 \\
\hline & ${ }^{\circ} \mathrm{C}$ & ${ }^{\circ} \mathrm{C}$ & ${ }^{\circ} \mathrm{C}$ & ${ }^{\circ} \mathrm{C}$ & ${ }^{\circ} \mathrm{C}$ & ${ }^{\circ} \mathrm{C}$ & & $\mathrm{m} /$ 秒 & $\mathrm{kw} / \mathrm{m}^{2}$ \\
\hline 1 月18日 & 3.3 & 3.2 & 2.8 & -0.5 & 0.5 & 3.8 & SW & 0.7 & -0.066 \\
\hline 1 月19日 & 4.9 & 4.9 & 4.4 & 0.2 & 0.5 & 4.7 & NW & 1.6 & -0.103 \\
\hline 1 月20日 & 1.3 & 1.3 & 1.0 & -2.0 & 0.3 & 3.2 & W & 2.2 & -0.107 \\
\hline 1 月 $21 日$ & 0.9 & 0.9 & 0.4 & -3.5 & 0.5 & 4.4 & SW & 1.1 & -0.114 \\
\hline 1 月 22 日 & 4.5 & 4.4 & 3.8 & 1.0 & 0.8 & 3.5 & SSE & 2.7 & -0.055 \\
\hline 1 月23日 & 3.0 & 3.1 & 2.8 & 1.6 & 0.3 & 1.4 & ENE & 2.6 & -0.055 \\
\hline 1 月 24 日 & 6.1 & 6.0 & 5.5 & 1.5 & 0.6 & 4.6 & W & 1.4 & -0.090 \\
\hline 1 月25日 & 5.8 & 6.0 & 5.7 & 4.9 & 0.1 & 0.9 & ENE & 2.8 & -0.010 \\
\hline 1 月26日 & 1.7 & 1.5 & 0.9 & -2.6 & 0.9 & 4.4 & W & 1.0 & -0.084 \\
\hline 1 月27日 & 4.6 & 4.5 & 4.0 & 1.2 & 0.6 & 3.3 & SSW & 1.4 & -0.051 \\
\hline 1 月28日 & 6.3 & 6.2 & 5.7 & 3.8 & 0.6 & 2.5 & $\mathrm{NE}$ & 3.0 & -0.083 \\
\hline 1 月29日 & 7.4 & 7.3 & 6.9 & 4.7 & 0.5 & 2.7 & W & 1.5 & -0.061 \\
\hline 1 月30日 & 2.0 & 2.1 & 1.8 & -0.8 & 0.2 & 2.8 & W & 1.4 & -0.075 \\
\hline 1 月31日 & 0.1 & 0.2 & -0.2 & -3.4 & 0.3 & 3.5 & WNW & 1.8 & -0.109 \\
\hline 2 月 1 日 & -2.5 & -2.4 & -2.6 & -5.0 & 0.1 & 2.4 & WNW & 2.4 & -0.107 \\
\hline 2 月 2 日 & -0.6 & -0.5 & -0.9 & -3.3 & 0.3 & 2.7 & W & 0.9 & -0.104 \\
\hline 2 月 3 日 & 1.4 & 1.3 & 0.8 & -3.3 & 0.6 & 4.7 & W & 1.3 & -0.107 \\
\hline 2 月 4 日 & 4.1 & 4.2 & 3.8 & 0.8 & 0.3 & 3.3 & SW & 2.2 & -0.102 \\
\hline 2 月 5 日 & 2.9 & 2.9 & 2.5 & -1.5 & 0.5 & 4.4 & W & 1.3 & -0.102 \\
\hline 2 月 6 日 & 3.8 & 3.7 & 3.1 & -0.2 & 0.8 & 4.0 & SW & 1.8 & -0.061 \\
\hline 2月 7 日 & 6.9 & 7.0 & 6.6 & 5.0 & 0.4 & 1.9 & $\mathrm{SE}$ & 1.6 & -0.012 \\
\hline 2 月 8 日 & 6.2 & 6.1 & 5.7 & 3.9 & 0.5 & 2.3 & $\mathrm{~W}$ & 0.9 & -0.054 \\
\hline 2 月 9 日 & 8.4 & 8.5 & 8.3 & 7.1 & 0.2 & 1.4 & WNW & 0.6 & -0.011 \\
\hline 2 月10日 & 3.6 & 3.7 & 3.3 & 0.2 & 0.3 & 3.4 & WSW & 1.0 & -0.091 \\
\hline 2 月11日 & 0.8 & 0.8 & 0.4 & -3.1 & 0.4 & 3.9 & WNW & 1.1 & -0.105 \\
\hline 2 月 12 日 & 2.6 & 2.4 & 1.8 & -1.9 & 0.7 & 4.4 & WNW & 0.8 & -0.080 \\
\hline 2 月 13 日 & 1.9 & 1.9 & 1.5 & -2.0 & 0.4 & 3.8 & WSW & 1.2 & -0.105 \\
\hline 2 月 14 日 & 3.5 & 3.4 & 2.9 & -0.6 & 0.6 & 4.2 & SW & 0.7 & -0.069 \\
\hline 2 月15日 & 7.7 & 7.7 & 7.2 & 5.3 & 0.4 & 2.4 & ENE & 3.5 & -0.019 \\
\hline 2 月 16 日 & 9.4 & 9.5 & 9.2 & 8.1 & 0.2 & 1.4 & E & 0.8 & -0.023 \\
\hline 2 月 17 日 & 8.4 & 8.5 & 8.2 & 6.6 & 0.2 & 1.9 & ENE & 2.6 & -0.042 \\
\hline 2 月18日 & 4.5 & 4.7 & 4.4 & 3.6 & 0.1 & 1.0 & ENE & 8.2 & -0.008 \\
\hline 2 月19日 & 7.5 & 7.4 & 7.0 & 5.4 & 0.4 & 2.0 & W & 1.2 & -0.048 \\
\hline 2 月 20 日 & 0.7 & 0.8 & 0.4 & -3.0 & 0.3 & 3.8 & SW & 1.3 & -0.114 \\
\hline 2 月 $21 日$ & 0.2 & 0.2 & -0.1 & -3.5 & 0.3 & 3.6 & WNW & 1.4 & -0.111 \\
\hline 2 月 22 日 & 3.3 & 3.2 & 2.6 & -0.9 & 0.7 & 4.3 & SSW & 0.8 & -0.069 \\
\hline 2 月 23 日 & 6.7 & 6.7 & 6.3 & 2.2 & 0.4 & 4.5 & W & 1.8 & -0.100 \\
\hline 2 月24日 & 5.5 & 5.6 & 5.3 & 4.5 & 0.1 & 1.0 & $\mathrm{SE}$ & 2.8 & -0.018 \\
\hline 2 月 25 日 & 4.1 & 4.2 & 3.9 & 0.2 & 0.3 & 4.0 & WNW & 1.5 & -0.098 \\
\hline 2 月 26 日 & -0.4 & -0.4 & -0.7 & -4.5 & 0.3 & 4.1 & WNW & 0.8 & -0.114 \\
\hline 2 月27日 & 1.4 & 1.4 & 1.0 & -2.7 & 0.4 & 4.0 & W & 1.0 & -0.095 \\
\hline 2 月28日 & 2.8 & 2.8 & 2.4 & -1.1 & 0.5 & 3.9 & W & 0.8 & -0.084 \\
\hline 3 月 1 日 & 1.7 & 1.5 & 0.8 & -3.2 & 0.9 & 5.0 & WSW & 0.7 & -0.101 \\
\hline 3 月 2 日 & 3.9 & 4.0 & 3.6 & 0.3 & 0.3 & 3.6 & SW & 0.6 & -0.078 \\
\hline 3 月 3 日 & 5.3 & 5.4 & 5.2 & 4.2 & 0.2 & 1.1 & ENE & 2.5 & -0.010 \\
\hline 3 月 4 日 & 3.2 & 3.2 & 2.8 & -0.3 & 0.3 & 3.5 & S & 0.8 & -0.078 \\
\hline 3 月 5 日 & 2.8 & 2.9 & 2.5 & 1.6 & 0.2 & 1.2 & $\mathrm{NE}$ & 2.9 & -0.041 \\
\hline 3 月 6 日 & 1.9 & 1.8 & 1.3 & -1.5 & 0.7 & 3.4 & W & 1.4 & -0.098 \\
\hline 3月 7 日 & 5.1 & 5.1 & 4.6 & 0.6 & 0.5 & 4.5 & W & 1.1 & -0.098 \\
\hline 3 月 8 日 & 8.8 & 8.8 & 8.4 & 4.5 & 0.4 & 4.3 & $\mathrm{~S}$ & 1.1 & -0.082 \\
\hline 3 月 9 日 & 10.1 & 9.8 & 9.1 & 4.0 & 1.1 & 6.1 & S & 1.4 & -0.080 \\
\hline 3 月10日 & 13.0 & 13.0 & 12.7 & 11.2 & 0.3 & 1.8 & WNW & 0.5 & -0.012 \\
\hline 3 月11日 & 10.5 & 10.5 & 10.2 & 8.7 & 0.3 & 1.8 & W & 1.5 & -0.044 \\
\hline 3 月 12 日 & 1.1 & 1.3 & 1.1 & -1.5 & 0.1 & 2.7 & SW & 1.5 & -0.094 \\
\hline 3 月 13 日 & -0.7 & -0.6 & -0.9 & -4.0 & 0.2 & 3.3 & WNW & 0.8 & -0.106 \\
\hline 3 月 14 日 & 1.0 & 1.0 & 0.4 & -3.0 & 0.6 & 4.0 & WNW & 1.2 & -0.085 \\
\hline 3 月 15 日 & 6.3 & 6.4 & 6.1 & 4.6 & 0.2 & 1.8 & WNW & 1.1 & -0.027 \\
\hline 3 月16日 & 9.4 & 9.2 & 8.6 & 4.7 & 0.8 & 4.7 & NW & 1.7 & -0.068 \\
\hline 3 月17日 & 12.5 & 12.5 & 12.1 & 10.5 & 0.4 & 2.1 & WSW & 2.1 & -0.040 \\
\hline 3 月18日 & 4.1 & 4.1 & 3.7 & -0.7 & 0.4 & 4.8 & W & 1.5 & -0.114 \\
\hline 3 月19日 & 5.5 & 5.4 & 4.8 & 0.7 & 0.7 & 4.8 & W & 2.0 & -0.090 \\
\hline 3 月 20 日 & 6.5 & 6.5 & 6.2 & 2.3 & 0.4 & 4.3 & SSW & 1.6 & -0.091 \\
\hline
\end{tabular}

1 ）風向と風速は牧之原 $\mathrm{AMeDAS}$ 観測值。それ以外は本試験において, 各月日の $19: 00$ か翌日07：00まで 1 分間隔で記録された平均值を示す。 


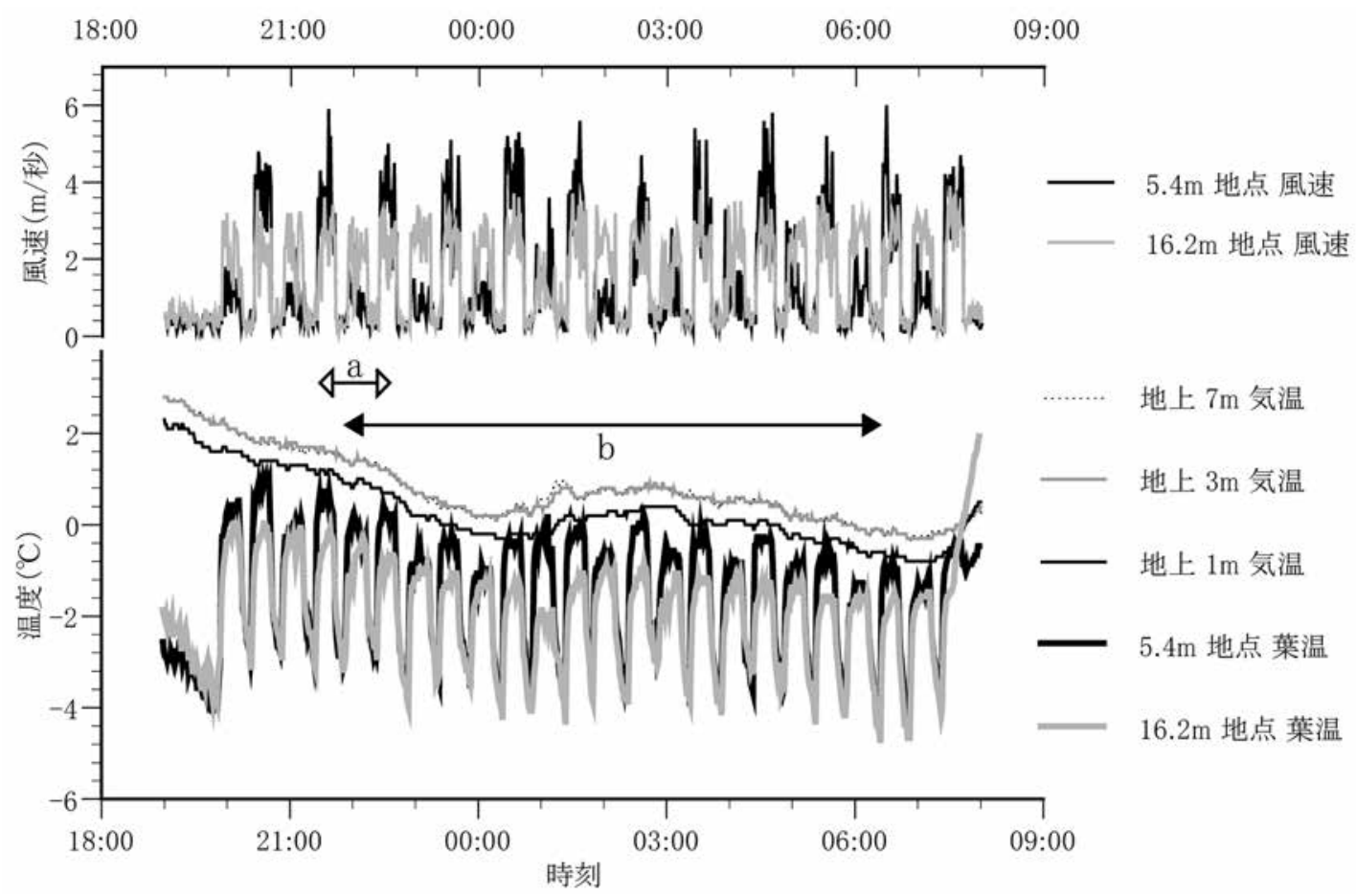

図 2 2005年 1 月21 22日の試験における高さ別気温, 樹冠面の葉温と風速の推移

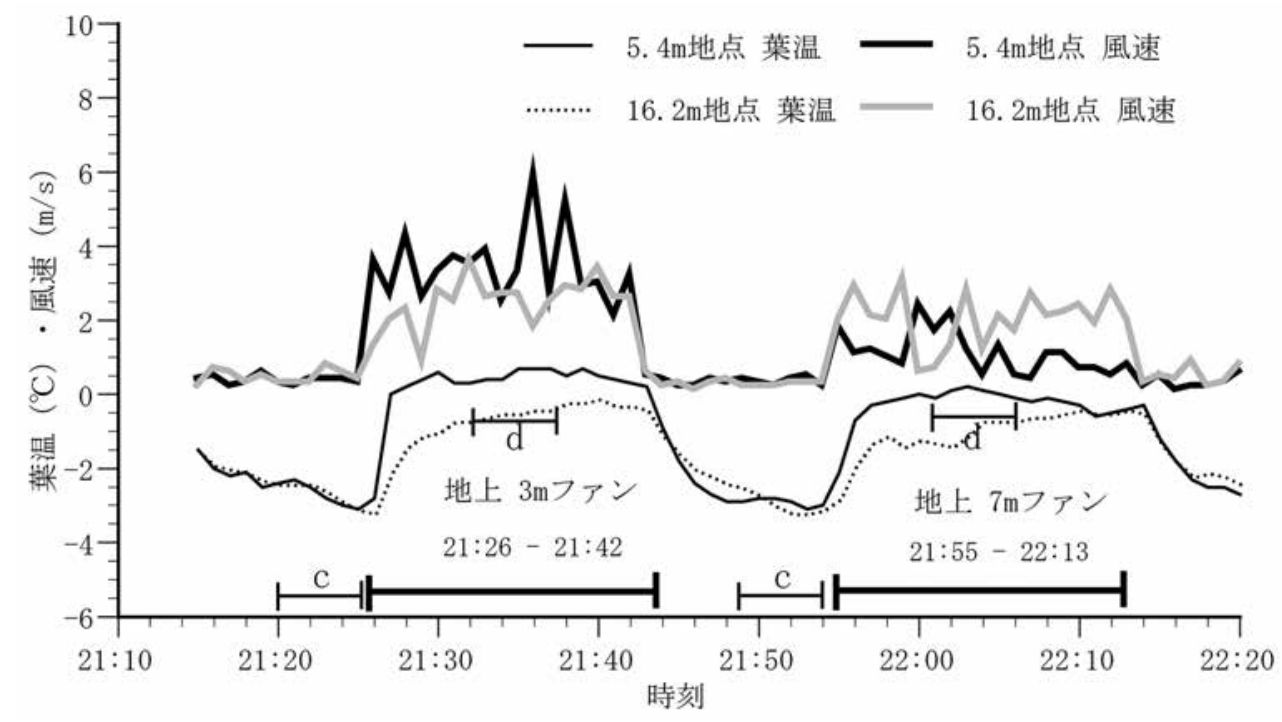

図 32005 年 1 月21日21:15 22:20における樹冠面の葉温と風速の推移

その結果，全ての調査日において，樹冠面の風速が早 いほど葉温上昇量も増加する傾向であった。しかし, 調 査日によって葉温上昇量や 9 回繰り返しでの変動幅には 違いが認められた。具体的には，1月21，2月20日， 2 月27日のように葉温上昇量が全て $4{ }^{\circ} \mathrm{C}$ 以下と小さいが, 繰り返しの分散が小さいケース，2月 5 日，2 月13日， 3 月 1 日， 3 月 18 日のように場所によっては $4{ }^{\circ} \mathrm{C}$ を超え
るほど葉温上昇量が高いが分散が大きいケース，および 2 月 3 日，3月 6 日のような中間型のケースに分かれた。

一方, ファンからの距離別観測点によっては, 特異的 な葉温上昇が認められた。地上 $7 \mathrm{~m}$ ファンの $5.4 \mathrm{~m}$ 地点で は, 風速が $2 \mathrm{~m} /$ 秒以下の弱い風であっても葉温上昇量 が大きく, 上述したケース II では $4{ }^{\circ} \mathrm{C}$ 以上の葉温上昇が 認められた。 

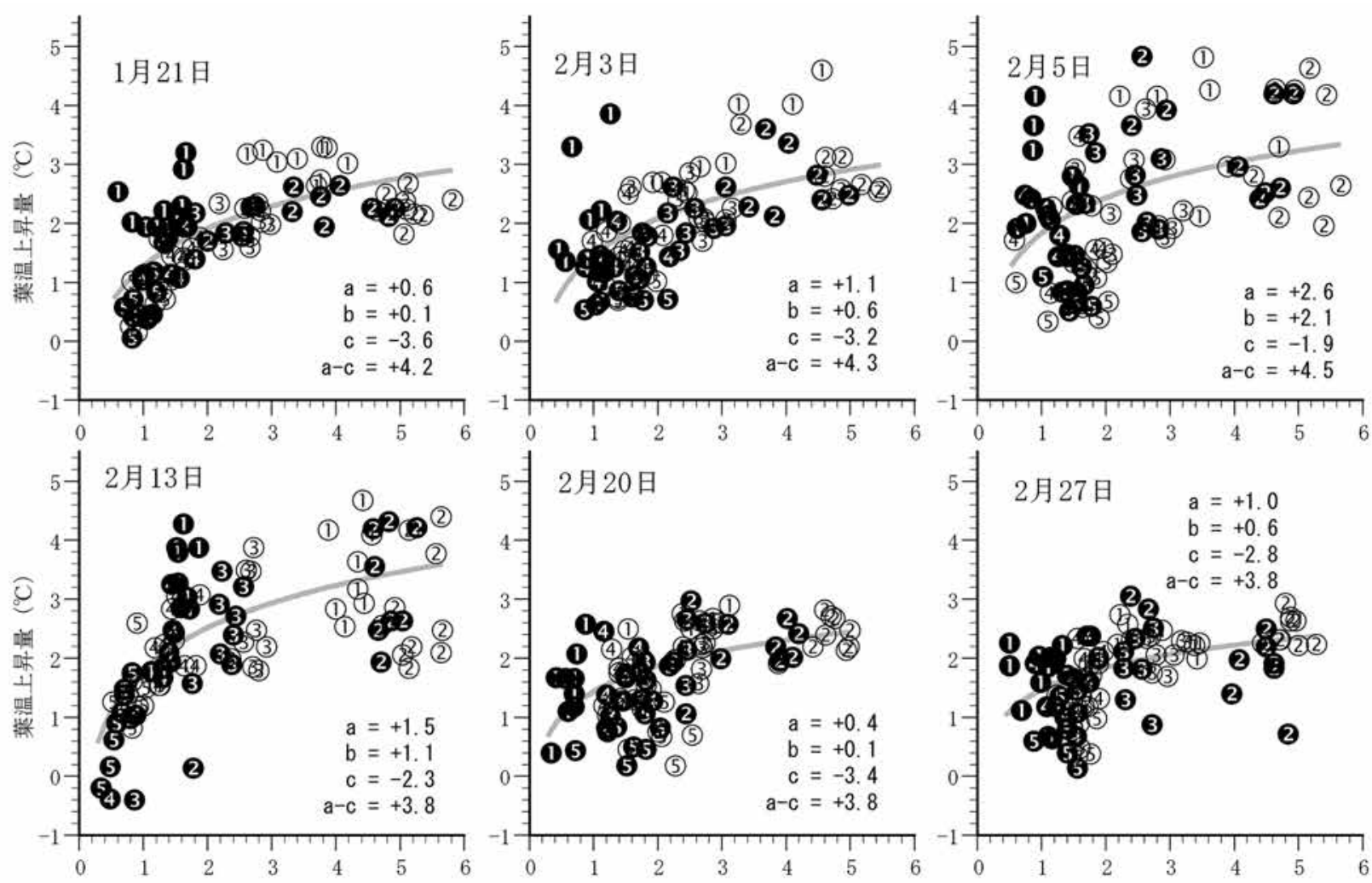

2月 20 日
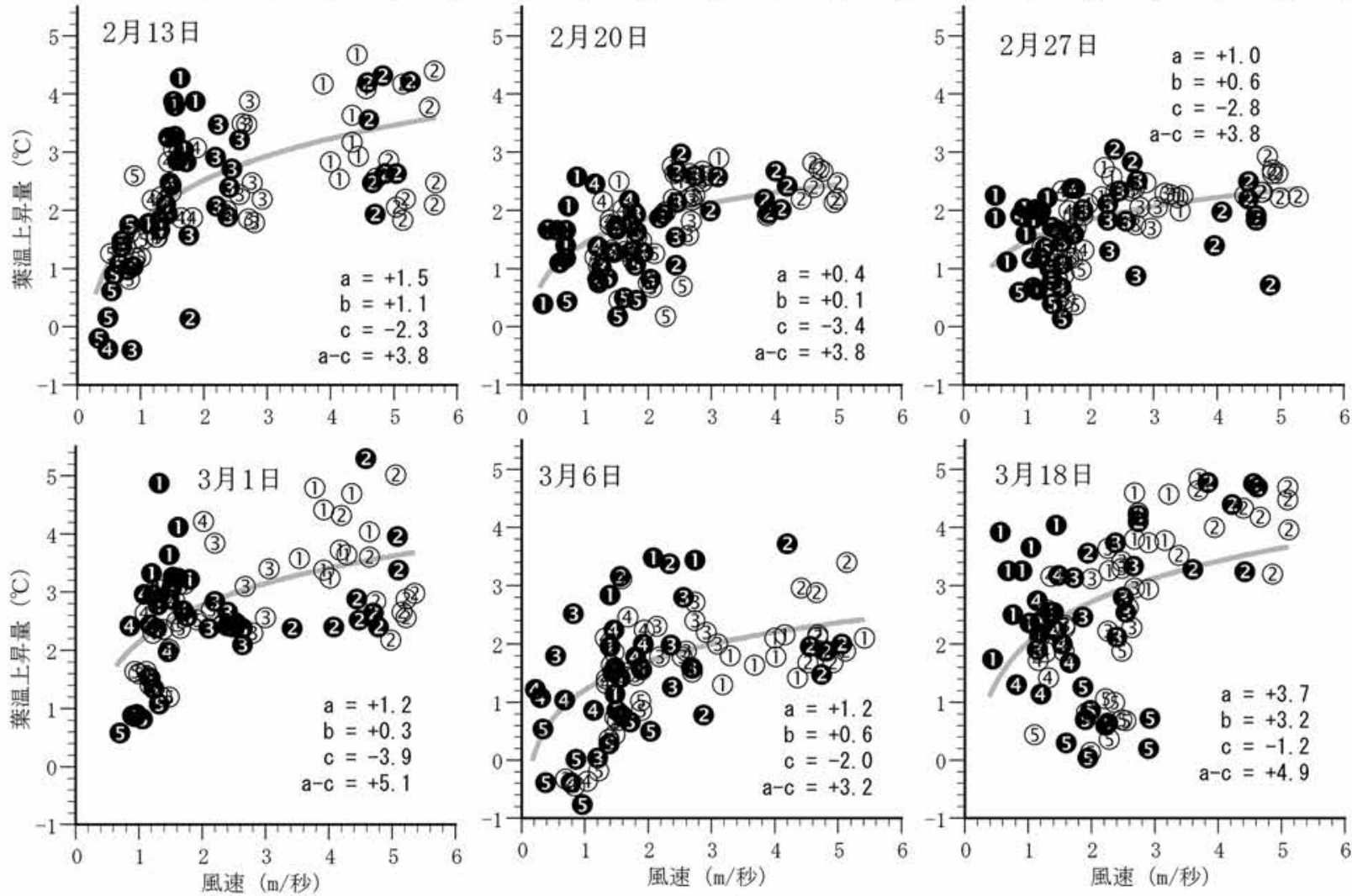

図 4 樹冠面の風速と葉温上昇量との関係

地上 $3 \mathrm{~m}$-距離5.4m (1)), 地上 $3 \mathrm{~m}$-距離 $10.8 \mathrm{~m}$ (2)), 地上 $3 \mathrm{~m}$-距離 $16.2 \mathrm{~m}$ (3), 地上 $3 \mathrm{~m}$-距離 $21.6 \mathrm{~m}$ (4)), 地上 $3 \mathrm{~m}$-距離27.0m (5)), 地上 $7 \mathrm{~m}$-距離 $5.4 \mathrm{~m}(\mathbf{1})$, 地上 $7 \mathrm{~m}$-距離 $10.8 \mathrm{~m}(\mathbf{2})$, 地上 $7 \mathrm{~m}$-距離 $16.2 \mathrm{~m}(\boldsymbol{3})$, 地上 $7 \mathrm{~m}-$ 距離 $21.6 \mathrm{~m}(\mathbf{4})$, 地上 $7 \mathrm{~m}-$ 距離 $27.0 \mathrm{~m}(\mathbf{\sigma})$, 地上 $7 \mathrm{~m}$ の平均気温（a), 地上 $1 \mathrm{~m}$ の平均気温（b), 平均葉温 $(\mathrm{c})$, 逆転度 $(\mathrm{a}-\mathrm{c})$

\section{4 考 察}

防霜に関する研究は, 本来ならチャの新芽が実際の被 害を受ける 4 月以降での降霜時に実施すべきとの考えが あろうが，その時期での降霜は突発的で葉温が氷点下に なる頻度は少ないので，安定したデー夕の取得は困難で ある。また, 本研究では, 夜間低温時の茶園における気 象環境を調べることが目的なので，低温になる頻度が高 い 1 〜月に試験を実施した。たた，厳冬期には強風を
伴った低温が多いことから，試験を実施した 62 日間の中 から 4 月以後の降霜時に類似した気象条件を呈した期日 を抽出して解析した。

その結果, 図 4 に示した 9 日間を含めて, 夜間の気 温は地上 $7 \mathrm{~m}$ と $3 \mathrm{~m}$ ではほとんど差がなく, 地上 $7 \mathrm{~m}$ と $1 \mathrm{~m}$ では0.1〜 $1.1^{\circ} \mathrm{C}$ の僅かな差が認められた。一方, 葉 温は地上 $7 \mathrm{~m}$ 気温より $0.9 \sim 6.1^{\circ} \mathrm{C}$ 低く, その差は正味放 射量が低い時に大きくなる傾向であった。筆者は2004年 2 月にも同じ場所で同様な実験を行ったが，地上 $7 \mathrm{~m}$, $5 \mathrm{~m}, 1 \mathrm{~m}$ の気温がそれぞれ $3.0^{\circ} \mathrm{C}, 2.5^{\circ} \mathrm{C}, 0.5^{\circ} \mathrm{C}$ に対して, 
葉温が- $7.0^{\circ} \mathrm{C}$ を記録したことがあった。此本らは，地上 $2,4 ， 6 ， 10 \mathrm{~m}$ の気温と葉温の推移を調査したが, 本 研究結果と同様に高い場所ほど気温は高いが，その差は 小さく, 気温と葉温との格差の方が大きかった ${ }^{6)}$ 。高市・ 米谷は, 正味放射量 $-0.09 \mathrm{~kW} / \mathrm{m}^{2}$, 風速 $0.3 \mathrm{~m} /$ 秒の場合, 地上 $1.5 \mathrm{~m}$ の気温と樹冠面葉温との温度格差が $5.5^{\circ} \mathrm{C}$ に及 ぶと計算した ${ }^{15)}$ 。

このように，放射冷却時の茶園では，気温と葉温との 格差が極めて大きい特性がある。果樹では，防霜の対象 となる花や果実は枝の下方にあり, 周辺の枝や葉からの 放射フレックスを受けるためか, 植物体の温度は周辺の 気温と大きく変わらない傾向がある ${ }^{16)}$ 。しかし, 機械摘 採のため表面を平らに整形された茶樹の樹冠面では，葉 は天空に向けて剥き出しの状態になっていることから, 他の物体からの放射フレックスを受けずに冷却し続ける ことが温度格差の原因と考えられる。

ところで, 栽培現地で発生している凍霜害は, 被害が 茶園内の局部に集中することがほとんどで, 傾斜地の斜 面方向では東〜南東側，南北うね茶園では樹冠面の東側 に被害が発生することが多い77)。中野・松尾は熱画像によ る解析の結果, 南北うね茶園では樹冠面の西側が東側よ りも葉温が高いことを明らかにし, その原因については, 西高東低の冬型気圧配置からもたらされる西からの微風 が樹冠面の西側に当たって温度が高まると考察した ${ }^{18)}$ 。

以上に示した 2 点（1夜間冷却時には地上 $1 \sim 7 \mathrm{~m}$ で の高さ別の気温に大きな差はないが, 気温と葉温との差 は大きい，(2)実際の場面では，気温よりも温度低下した 葉に風が当たった部位は凍霜害が抑制されている）も考 慮して, 筆者らは, 送風法による主要な防霜効果は, 「高 所から暖かい空気を下方に降ろして茶樹付近の空気を暖 める」ではなく、「放射冷却によって低温になった樹冠 面に風を吹き付けて直接暖めること」と仮説を立てた。 本研究では, それを明らかにするため, 防霜ファン茶園 内の数力所に風速計と温度計を併設して観測を行い, 風 速と葉温上昇量との関係を調查した。

その結果は図 4 に示したと扔りで, 送風するファン設 置の高さ（地上 $7 \mathrm{~m}$, 地上 $3 \mathrm{~m}$ ）に関倸なく, 樹冠面の 葉温上昇量は風速に大きく依存している傾向が認められ, 筆者らの仮説の正当性を伺わせた。しかしながら，ファ ンの間近である $5.4 \mathrm{~m}$ 地点では風速が小さいにも関わら ず，高い温度上昇が認められた。この現象が「高所から 暖かい空気を下方に降ろして茶樹付近の空気を暖める」 による効果かどうかについては不明であるが，本研究で はその現象が少面積だったので，茶園全体の葉温上昇効
果に及ぼす影響はそれほど大きくなかったと考えられる。 本研究では, ファン稼働直前と稼働後の短い時間に抄 ける葉温の格差を葉温上昇量としたが, 実際の場面では 防霜ファンは数時間連続して稼㗢する。本研究で認めら れた風速に起因しない葉温上昇が, 防霜ファンを長時間 稼働させた場合や異なる地形条件でどのような影響を受 けるのかを確認しなければならない。また, 図4で示さ れた調査日によって葉温上昇量や変動幅が異なる原因に ついても詳細な検討が必要である。

なお，本研究での調査対象は「葉温上昇効果」であっ て,「防霜効果」でないことを改めて述べておく。

\section{5 摘 要}

防霜ファンからの距離5.4，10.8，16.2，21.6，27.0m地 点の樹冠面に温度計と風速計を併設して, 防霜ファンの 稼働による樹冠面の風速と葉温上昇量との関係を調查し た。10.8 27.0m地点では, 風速が大きいほど葉温上昇 量が増加したが, 防霜ファンから最短の $5.4 \mathrm{~m}$ 地点では 風速が小さいにもかかわらず葉温上昇量が大きかった。 以上の結果より, 送風法による茶園での葉温上昇効果は, 風が樹冠面に当たることに依存すると考えられるが，防 霜ファンに近い範囲では風速に起因しない葉温上昇が認 められた。

\section{6 引用文献}

1 ) 静岡県経済産業部農林業局茶業農産課（2013）：静岡県茶業の 現状〈お茶白書〉. 静岡, 61 .

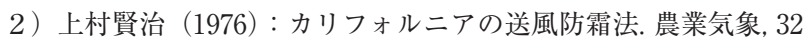
(3), 155-159

3 ）青野英也 (1980)：チャの凍霜害関係研究文献集録. 農林水産 省農林水産技術会議事務局.

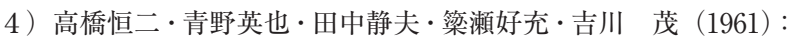
茶樹の凍霜害に関する研究. 降霜時の微細気象と凍霜害の応急 的ならびに栽培的防止法の研究. 東近農試研報, 茶業部, 8, 28 -151 .

5 ）木村政美 - 大石貞男 $\cdot$ 日高 保（1966）：防霜用送風機の効果 に関する研究. 静岡県茶業試験場研究報告. 第 1 号, 23-36.

6 ）此本晴夫 ·鈴木幸隆 - 木村政美 - 岩崎正男 - 木村 進 - 小野 循男（1976）: 茶園に抢ける小型ファンの防霜効果. 静岡県茶 業試験場研究報告. 第 7 号, 43-57.

7 ) 静岡県農政部茶業農産課 (1998): 平成10年静岡県茶業の現状. 静岡, $27-28$.

8 ) 本条 均 (1997)：防霜. 新編農業気象学会用語解説編集委員 会編. 新編農業気象学用語解説集. 日本農業気象学会, 157.

9 ) 此本晴夫 (1988) : 茶樹の気象災害防止法. 社団法人静岡県茶 業会議所編, 新茶業全書, 社団法人静岡県茶業会議所, pp.184196.

10）筞瀬好充（1994）：茶園の気象災害. 岩浅潔編. 茶の栽培と利用 
加工. 養賢堂, pp.245-265.

11）坪井八十二 (1986)：気象と農業生産. 養賢堂, pp.195-197.

12）中野敬之 (2008) : 気象災害と対策 凍霜害. 社団法人農山漁村 文化協会編. 茶大百科 II. 社団法人農山漁村文化協会. pp.471480.

13）中野敬之・丹羽明広（2003）：防霜ファンの高さが葉温の上昇 効果に及ほす影響. 農業環境工学関連5学会2003年合同大会講 演要旨, 78 .

14）中野敬之・成田和隆・丹羽明広・関口幸彦（2004）：昇降式防 霜ファンの俯角が茶株面の葉温上昇効果に及ぼす影響. 農業環
境工学関連 4 学会2004年合同大会講演要旨, 157.

15）高市益之・米谷 力（1993）：冬季の成木茶園に扔ける温度分 布と樹体の凍結・融解. 農業気象,49(2), 81-90.

16）中川行夫・小中原 実・岩崎正男・岩崎尚・上村賢治（1993）： 低温時におけるカンキッ園のウインドマシンによる温度上昇 効果. 農業気象, 48(4), 375-378.

17）青野英也・筞瀬好充・田中静夫（1974）：1972年春の茶園凍霜 害の実態. 茶研報, No.41, 16-36.

18）中野敬之·松尾喜義（2000）：南北うねの弧状樹形茶園におい て茶株面の東側に凍霜害が集中する原因. 茶研報, No.88, 9-24. 